\title{
sciendo
}

DOI: $10.2478 /$ abcsj-2019-0023

American, British and Canadian Studies, Volume 33, December 2019

\section{How the Booker Prize Won the Prize}

\author{
MERRITT MOSELEY \\ University of North Carolina at Asheville, USA
}

\begin{abstract}
This article shows that the Booker Prize for fiction, which is neither the oldest nor the richest award given for novels in English, is nevertheless widely conceded to be the pre-eminent recognition. Sometimes it is called the "most significant"; sometimes the "most famous"; ultimately these two qualities are inseparable. I canvass some of the explanations for the Booker's position as top prize and argue that the most important reasons are Publicity, Flexibility, and Product Placement. The Booker has managed its public image skillfully; among the devices that assure its continued celebrity is the acceptance, almost the courting, of scandal. Flexibility is partly a function of the practice of naming five new judges each year, but the Booker has also been responsive to challenges, including the recognition that it paid too little attention to female authors. The decision to admit American books into the competition was a sign of flexibility, as it was a guarantee of scandal. And the Booker has followed a path of "product placement" that positions it accurately between demands for high art and for "readability," as examination of several periods in its history demonstrate.
\end{abstract}

Keywords: Booker Prize; scandal; shortlist; popular novel; literary novel; Martyn Goff; American; Orange Prize; publicity; product placement

Anthony Thwaite, writing in 1986, declared that The Booker Prize "is internationally recognized as the world's top fiction prize." An English author who was a Booker judge at the time, he may be suspected of some partisan overreach. But American literary editor Laura Miller concurred when she called the Booker "the best literary award." In what follows, I undertake to investigate what it might mean to be the "top" literary award, analyze how the Booker developed into what appears to be its superior 
position among the many, many existing prizes for fiction, and offer an explanation of what makes it supreme. In brief, it is not its antiquity, as there are many awards much older, or its monetary value, though that is high, as there are richer awards, but a more subtle mixture of flexibility, the management of publicity including "scandals," and product placement.

The Booker Prize dates from 1969. One of the founders, publisher Tom Maschler, relates that when he first found himself working in British publishing, after some time spent in France, he "learned that there were a number of literary prizes in England also," but that they were not "significant" in the same way as the French Prix Goncourt. Significant in what sense? Maschler reveals that what he means is "extra sales generated by a book winning one of these prizes" (15). So, at the outset at least one of the founders had in mind not so much recognizing artistic excellence he knew that other prizes were doing that - but publicizing books and authors in the interest of selling more books.

Maschler mentions the Somerset Maugham Award. Established in 1947 and endowed by Maugham, it initially recognized one novel by one young novelist who was required to use the modest prize money for foreign travel. (It now gives several prizes in any year whose authors divide a total prize fund, most recently of £19,000). In 1969 there were also the Guardian Fiction Prize, founded in 1965, and the Geoffrey Faber Memorial Prize (1963), not to mention the two really venerable awards, both established in 1919, the James Tait Black Memorial Prize and the Hawthornden Award.

Commentators on the Booker Prize regularly point to its success in generating extra sales for the winner as well as the novelists who make the six-book shortlist - Maschler's metric for a significant prize - though proving the causation in this case is not easy. Nevertheless, since its founding it has indeed come to be thought of in a way that differentiates it almost completely from the James Tait Black or the Somerset Maugham. A small number of tributes may stand in for a wider climate of opinion: "It's already the most famous book prize in English-language writing ... the most important literary prize" (Luke Brown); "The Booker Prize is the most famous arts sponsorship of all time" (Man Booker 19); the "prize has established itself as a British institution, rather like Derby Day" (Booker 
30 50); "perhaps the most significant annual international award in English letters" (Strongman vi). This encomium from James F. English is revealing in its criteria for the Booker's success: "Just a decade after its near collapse [it was quite imperilled in the first few years], the Booker outstripped all other British literary prizes combined in terms of the sheer volume of publicity, renown, and book sales it could generate for its winners" (114). ${ }^{1}$

Jason Cowley's comment on the role of the Booker and others, in what he calls "the age of awards," is telling. At stake, he maintains, are "recognition, symbolic capital, prestige. Prizes create cultural hierarchies and canons of value." Indeed, and there are, in turn, hierarchies and canons of value among the prizes themselves, with the Booker Prize clearly situating itself at the top of the hierarchy.

The prize money, $£ 5000$ in 1969 , was considerable. This is one way the Booker is unlike the Prix Goncourt, acknowledged as its inspiration: the Goncourt is currently worth $€ 10$, while the prize money for the Booker has climbed to $£ 50,000$, with the shortlisted authors receiving $£ 2500$. The Booker is by far the most lucrative literary prize in the UK. But it is not the richest literary prize by a very long way. For instance, the Nobel Prize for literature carries an award of over one million dollars, there are several awards from the UAE worth several hundred thousand dollars (including one that gives $\$ 1.3$ million for a single poem), and at least ten awards worth $\$ 100,000$ (about $£ 80,000$ or $€ 88.000$ ), based in the United States, Qatar, Mexico, Nigeria, and South Korea. The International Dublin Literary Award, previously the Dublin IMPAC Award, is worth $£ 100,000$, twice the value of the Booker.

Luke Brown calls the Booker prize the most important literary prize; but his earlier characterization of it as the most famous book prize in English-language writing conflates renown with other kinds of significance and points to the feature which, more than any other, distinguishes the Booker from other UK literary awards: canny management of publicity. The Booker-choosing process produces headlines, interviews, and analyses for months before the award is announced. Several features assure a high public profile. One of these is the longtime administrator, Martyn Goff, who ran the competition from 
1970 to 2006. Sir Michael Caine, the CEO of the original sponsors, Booker plc, commented on Goff's role: "to arouse the interest of journalists and diary columnists in some aspect of the year's happenings never saying sufficient to give an official view, but always sufficient to start the journalists hunting the hare" (15). The Booker procedure has always offered multiple bursts of publicity, spread out over months.

First, the judges were announced. From the beginning, five notable persons would usually be appointed to do the judging each year (though there were only three in 1972, 1974 and 1976). One feature that has helped to raise the news value of the judging panel is the inclusion, much of the time, of a nonspecialist among the literary journalists, academics, and authors who dominate the panels. Often a member of Parliament fills that fifth slot; others have included Rabbi Julia Neuberger, now a Baroness; Mary Wilson, wife of former Prime Minister Harold Wilson; actors Dan Stevens and Joanna Lumley; and David Baddiel, a comedian. This group of judges spends several months reading the nominated books, usually somewhere between 150 and 200 titles. They produce a longlist of 10-13 semifinalists, a list which originally was confidential, but, following an unauthorized but inevitable disclosure, began to be publicized some years ago. In September the shortlist, now always six novels, is released to the press and public, and in October the winner is announced, at a lavish ceremonial dinner, held in London's Guildhall, and broadcast live on television. This series of events provides for discussion, argumentation, and controversy over at least four decision points: choice of judges, longlist, shortlist, winner. Even a longlist of 13 books will exclude nearly all the hundreds of novels eligible for consideration and some of those exclusions will seem indefensible as, of course, will some of the inclusions. There is also a great deal of betting on the Booker, with High Street bookmakers setting odds on each of the shortlisted books.

Over the fifty years of the Booker, the move in 2013 to change the terms of the award has stimulated the most continuing discussion and controversy. Before that time the winning book had to have been published in England and in English during the period of eligibility, and written by an author from the UK, the British Commonwealth, the Republic of Ireland, or Zimbabwe. In effect, any English-language author 
from anywhere in the world except for the United States was eligible. Beginning with the judging in 2014, American authors became eligible and in the five years since then, two of the winners have been from the US.

Another potent engine of Booker publicity, a means of "building the brand," Booker Prize was launched. In 2004 it was followed by the Man Booker International Prize, now known as the International Booker, an award initially given every two years to a world author and now given every year to an international book translated into English, with the $£ 50,000$ award money divided between author and translator. In 2010, the Lost Man Booker Prize was selected from books that were published in 1970, when a change in the rules precluded their being considered: it went to J. G. Farrell's Troubles. There have also been a "Booker of Bookers," in 1993, selected by three previous chairs of judges, and the Best of the Booker, chosen in 2008 by a public vote, both of these won by Salman Rushdie's Midnight's Children; a "Best of Beryl" prize in 2006 to reward Beryl Bainbridge, famous for never winning despite frequent nominations; and the Golden Man Booker, awarded in 2018. This involved the naming of five judges, each of whom reviewed the winners for one decade of the Booker and named the best of that decade, after which a public vote on those five finalists gave the prize to Michael Ondaatje's The English Patient.

A special kind of publicity, and one particularly potent in raising the Booker to the top of the literary-award rankings, is scandal. English has written pungently about the way that "scandal, or the threat and promise of scandal, is constitutive of prizes as we know them" (113). And this is particularly true of the Booker which, as he explains, starting in 1971 (the third year of its existence) has delivered "a series of annual scandals" (114). "Far from posing a threat to the prize's efficacy as an instrument of the cultural economy," he continues, "scandal is its lifeblood; far from constituting a critique, indignant commentary about the prize" - the annual journalistic tut-tutting over the newest scandal - "is an index of its normal and proper functioning" (115). The scandals are of many kinds; one annual but fairly low-key scandal is the omission of 
names from the long- or short-list, most notably Martin Amis, who has been nominated before but never won, and Salman Rushdie, who has won the prize in 1981, as well as two cumulative awards. The headlines regularly note, in any year when he has an eligible novel that does not appear on the shortlist, that Rushdie has been "snubbed."

Other scandals arise from the behavior of the nominees and winners, most notably when John Berger, who received the Booker in 1972, used his speech to denounce the sponsors, Booker-McConnell plc, and promise to donate his prize money to the Black Panthers; or when Rushdie reportedly stormed out in fury after his shortlisted Shame did not win in 1983; or when John Banville urbanely commented on his own 2005 victory, with The Sea: "It is nice to see a work of art win the Booker Prize," continuing, "There are plenty of other rewards for middle-brow fiction. There should be one decent prize for ... real books" (Brockes). Sometimes the winning novel itself can be construed as a scandal, a journalistic boon delivered by James Kelman's How Late It Was, How Late (1994) and 2003's Vernon God Little, by the pseudonymous DBC Pierre. Sometimes one of the judges causes scandal, as when judge Julia Neuberger, outraged over the award to Kelman, disassociated herself from the decision, or when one of the judges admits to not having read all the nominated books or testifies to a literary taste for light reading. The 2019 judges created a different kind of scandal. Unable to choose one winner, they determined to flout the rules of the award, despite being told they could not by the Booker administrator, and split the prize between Bernardine Evaristo and Margaret Atwood.

How is this scandal generated? English gives longtime administrator Goff ample credit, noting that he "was fully and actively complicit in exploiting the association of the Booker with scandal, wagering that the prize stood to reap the greatest symbolic profit precisely from its status as a kind of cultural embarrassment" (115). Goff himself, interviewed by Ion Trewin, seems to chortle over some of the scandals he had witnessed - and in part encouraged - "with a certain frisson" (Trewin 22). Goff is quite candid about the wrangles among the judges, the role played by their personalities and quirks, and the result that the "year's best novel in English" is sometimes chosen by strange - even scandalous - 
procedures. Richard Todd sums up the role of scandal: "It is surely evident that it is precisely by 'getting it wrong' that the Booker survives"' (64).

The nature of the judging, however, is sometimes mentioned as the reason for the Booker's preeminence. Each year there are five new judges (though some have judged it more than once), a unique panel, with one named as chair. The chair is sometimes forceful and insistent, sometimes self-effacing, sometimes even helpless. The judges presumably begin with established ideas about some of the authors nominated, and in many cases, since they are literary people, they have reviewed some of the books before finding themselves passing judgment upon them.

A bookseller (and it is worth remembering that the original purpose of the Booker was to increase book sales) declares that "The beauty of The Booker Prize is its unpredictability. No two years are the same, because no two years of judging are the same. The Booker, like fiction in general, is very much a matter of personal choice and nowhere is that choice made more public than in the annual shortlist, followed by the winner" (Anderson 26). Miller, literary editor of Salon, who calls the Booker the best literary award, offers a different observation, saying that the "most important factor in the Booker's success is the diversity of its judges." She contrasts the Booker judges with those for the American Pulitzer Prize, most of them newspaper editors and professors of journalism, and the National Book Awards, the other leading American prize, which are judged by fellow practitioners, so that the novel award is chosen by novelists. Miller notes the competitiveness of writers, suggesting that it may warp the decisions on the National Book Awards, and concludes that the Booker benefits because of the "civilian perspective" that results from the inclusion of nonspecialists. One might also consider the relative transparency, as well as diversity, of Booker judges by contrast with those who select the Nobel Prize for Literature, the eighteen life members, mostly obscure everywhere but Sweden, of the Swedish Academy. Another sharp contrast to the Booker's rules comes from the James Tait Black Memorial Prize, which is chosen by the Professor of English Literature at the University of Edinburgh, assisted in choosing the shortlist by postgraduate students in that department. 
Though the judges change every year, the stated criteria for the winner remain relatively unchanged. Nevertheless, the Booker demonstrates considerable flexibility. In its first few years the shortlist comprised mostly British and Irish authors, but quite soon the shortlists and winners began to broaden their reach to include more books from the Commonwealth. As early as 1971, V. S. Naipaul took the award with his book In a Free State. ${ }^{3}$ The Booker was slower to recognize its ongoing neglect of women authors. In 1991, for instance, there were no women on the shortlist, while in each of the next four years there was only one. There were nevertheless women victors in that period, Pat Barker in 1995 and Arundhati Roy in 1997.

The Orange Prize for women's fiction (now the Women's Prize for Fiction) was created in 1996 as a result of dissatisfaction with Booker's underrepresentation of women and specifically its oversight of Angela Carter. One aspect of Booker's flexibility is its capacity for responding to challenges from other awards, while giving no sign of doing just that. In the $21^{\text {st }}$ century, only one shortlist (2008) has contained a solitary woman, four $(2003,2006,2013,2018)$ have had four women, and women have won seven of the prizes, including two victories for Hilary Mantel, who becomes the only female (and only English) two-time winner.

Another challenge that has been answered with a major adjustment (and indeed a major scandal) has been the inclusion of American authors. From the beginning, the Orange Prize was open to American authors; so was the International IMPAC Dublin Literary Award. A new challenger to the Booker, initially called the Literature Prize (later the Folio and now the Rathbones Folio Prize), appeared in 2014; it was also open to any book written in English, that is, to Americans. Its announcement, in March 2013, was followed by the announcement, in the following September, that its new terms of eligibility also included American authors. (It is true that the change had been discussed, not very urgently, for some years before it occurred.)

Letting the Americans in has had two results that highlight the Booker's flexibility and its role in retaining a place at the top of the cultural hierarchy: reducing the contrast with other awards that might seem, or aspire, to constitute serious competition to the Booker's ranking, 
and generating enormous publicity, including scandal that continues years after the decision (cf. Cain and Yeginsu).

The final explanation for the Booker's continued pre-eminence is what one might call product placement. To say that the award goes to the best original novel written in English during the year is easy; to say what kind of novel the winner represents is a different matter entirely. Over the years the Booker has quite cannily kept to a middle ground between the two poles of English-language fiction that might be called Mandarin and populist. That it has been criticized from both sides is a sort of testimony to its success in finding a sweet spot, as are the failed efforts of competing book prizes on either the right or left, the high-modernist or escapistreadable wings.

The Booker has historically focused on what might be called "serious literary fiction"; in this usage, "literary" is distinguished from "popular," though of course popular fiction is also, strictly speaking, literary and some literary novels (Schindler's Ark, Booker 1982, being a spectacular example) are popular in the sense of selling many copies and being treasured by many people. Todd discusses the terminological niceties: "Serious literary fiction tends to exclude best-selling genrefiction categories such as crime or science fiction but may make use of some of the conventions of these genres" (7). Alluding to the widespread discussion of the popular-literary divide, Todd goes on to state, quite reasonably, that the most useful definition of the literary novel is "Bookereligibility" (7). But not without challenge.

The argument that Booker novels are too difficult, too lapidary, too short of plot, often relies on the shorthand appeal to "readability," which seems to mean easy or uncomplicated readability. Nick Hornby, himself a popular novelist often pigeonholed as a purveyor of "Ladlit," is a sharp critic of the literary novel. A widely read man, he nevertheless writes that "I'm sure I'm not the only one who harrumphs his way through a highly praised novel, astonished but actually rather pleased that so many people have got it so wrong. As a consequence the first thing to be cut from my reading diet was contemporary literary fiction" (13). He attributes the prestige of the literary novel to a belief that reading should be hard work, 
something the reader grinds through, rather than reads for enjoyment, concluding with this manifesto:

I don't mean we should all be reading chick lit or thrillers (although if that's what you want to read, it's fine by me, because here's something else no one will ever tell you: if you don't read the classics, or the novel that won this year's Booker Prize, then nothing bad will happen to you; more importantly, nothing good will happen to you if you do); I simply mean that turning pages should not be like walking through thick mud.

An anonymous reviewer in Private Eye defined the prescription for a successful Booker winner from somewhere near Hornby's position: "foreign, funny name, 'poetic' prose style and so on" (Wheen 17). Rather odder, and more worrying for defenders of the Booker, are implicit attacks on its remoteness from the ordinary reader by those chosen to judge it. In 1984, the chair of judges, an Oxford historian, off-handedly declared that they would have had no interest in "a Proust or a Joyce," not that he had ever read either of them (Lee).

In 2011 several of the judges made alarming comments. The chair, Stella Remington, a retired spy who was the author of some thrillers that were partially ghost-written, announced, in explaining what the judges meant by the stated criterion of "readability," "We want people to buy and read these books, not buy and admire them" (qtd. in Mark Brown), with a sly innuendo that admirable books were not read, readable books not admired. Chris Mullin, another judge (a politician rather than literary figure) insisted that successful books had to "zip along," while Susan Hill, a novelist and critic on the judges' panel, rather defensively tweeted, "Hurrah! Man Booker judges accused of 'dumbing down.' They mean our shortlist is readable and enjoyable," and her fellow judge praised one of the shortlisted novels, Jamrach's Menagerie, in populist terms: "It's set in a very Dickensian world but the language isn't arch, it isn't difficult, it doesn't try hard in any way" (qtd. in Bennett). All of this panicked some observers. Should the Booker Prize be reserved for books that do not try hard in any way? Should they be easy to read, to zip along?

The suspicion of dumbing down led to a probably excessive suspicion of the shortlisted books, which were hardly potboilers or genre 
novels; still, many more traditional observers considered only one of them, Julian Barnes's The Sense of an Ending, a proper serious literary novel by anybody's standards (Barnes had been shortlisted twice before, while several of the other finalists were by little-known or debut novelists). Barnes did win, but the worry about dumbing down, about "readability," about the panel's "philistine attacks on literary fiction" (Clark), about the judges' move to open up what former poet laureate Andrew Motion denounced as "a completely false divide between what is high end and what is readable, as if they are somehow in opposition to one another, which is patently not true" ("Never Mind") - this swelling tide of opposition eventuated in the creation of a new award, originally called The Literature Award, which was designed to "establish a clear and uncompromising standard of excellence" (Clark). Clearly the organizers mean to reaffirm the serious literary novel in the face of a Booker Prize seen as turning against literary quality in the name of "readability." Soon the Folio Society, a publisher, became the sponsor and the prize was funded at a near-Booker level of $£ 40,000$. It was first awarded in 2014. There has been a somewhat spotty history since then: after the first two years, there was no award in 2016; beginning in 2017 there was a new sponsor, Rathbone Investment Management, a new lower prize level $(£ 20,000)$, and a new definition, as nonfiction books became eligible. In 2019 prize money was increased to $£ 30,000$.

But what about the Booker's response to the 2011 outcry and the new award? It is possible that all the discussion of readability and zipping along - since in the end a universally acknowledged literary novel by one of England's most distinguished novelists took the Booker Prize - was another example of productive publicity in the form of scandal, a case of "getting it wrong" in the shortlist and the justifications but getting it right in the end. And what of the winners since that year? In 2012 it was the uncontroversial choice of Hilary Mantel's Bring Up the Bodies, the successor to her earlier winner Wolf Hall, and the following year the extremely ambitious, not to say difficult-to-read The Luminaries, by young New Zealander first-time novelist Eleanor Catton, an 832-page book organized around the signs of the zodiac, with some plot developments based on the movements of heavenly bodies. Other 
Bookers, like Marlon James's A Brief History of Seven Killings (704 pages, much of it written in Jamaican patois) or Anna Burns's Milkman, an unsettling and challenging read, show no signs of complicity with the demand for readability at the expense of ambition or art.

In addition to the Rathbones Folio Prize, and perhaps with no reference to the 2011 Booker contretemps, the Goldsmiths Prize was established in 2013 to celebrate the tradition of fine writing associated with Goldsmiths College of the University of London and "to reward fiction that breaks the mould or extends the possibilities of the novel form" (Goldsmiths Prize website). It is co-sponsored by the New Statesman magazine and carries a cash award of $£ 10,000$. Its shortlists have often overlapped in part with those of the Booker, and its 2014 and 2016 winners, Ali Smith and Robin Robertson, were both shortlisted for the Booker.

The challenge from what might be considered the other side, that is from the perspective of greater "readability" or "popularity," includes two awards sponsored by WH Smith, the popular chain of High Street bookstores and stationers. The WH Smith Literary Award predated the Booker, having been founded in 1959; it lasted until 2005, following several changes including the admission of American authors and foreign works in translation. Toward the end, the Fiction Award (along with several other categories including Home and Leisure and Children's Literature), was popularly chosen, with the public invited to vote on the winner from a shortlist provided by a panel of experts. The Booker Prize has always had the promotion of book sales as one of its purposes, but the sponsorship of this prize by WH Smith, which unlike Booker McConnell or the Man Group or Crankstart, the foundation that will sponsor the Booker from 2020, is actually in the bookselling business, may have tipped its choices in the "readable" - i.e. marketable - direction.

The shorter-lived WH Smith Thumping Good Read Award was more frankly populist. Running from 1992 to 2003, it featured "accessible" fiction and its winners were chosen by a panel of WH Smith Customers. In 2018 it was revived to celebrate books that readers cannot put down. The winner is to be chosen in a mixed fashion; $50 \%$ of the decision is made by celebrity judges, romance novelist Jojo Moyes and 
Peter James, author of crime fiction; the other half via online voting by the public.

The Booker has established a channel that runs between awards like those sponsored by WH Smith, especially the "Thumping Good Read," and those, like the Goldsmiths Prize and the Rathbones Folio Award, exist to challenge calls for "readability" and books that zip along. Moreover, it has smoothly made mid-course corrections. That this was conscious and intentional seems unlikely, since the judges in any given year are entirely different from the ones in the previous year.

Consider 2016-2018. In 2016 the winner was Paul Beatty's The Sellout, which has at least two distinctions: it is a comic novel, quite unusual among Booker prizewinners, but more importantly, it was the first American winner. In 2017 George Saunders, with Lincoln in the Bardo, was the second consecutive American winner. There were rumblings. This was exactly the sort of development that some critics of the decision to admit American candidates had warned of - American domination of the Booker. Observers were very keen to see what would happen in 2018: and sure enough, though there were two Americans on the shortlist, the award returned to the British Isles with Anna Burns's Milkman. Of course there were no instructions issued and the judges chose the book they believed was the best novel in English in 2018; but it was a correction nonetheless.

Or consider the stretch of choices from 1984 to 1988. In 1984 the prize was won by Anita Brookner's Hotel du Lac, a fairly conventional well-made novel about the emotional and romantic difficulties of a middle-class Englishwoman. In the following year the pendulum swung very strongly, as the jury chose Keri Hulme's The Bone People, usually considered the most rebarbative winning book in the fifty years of the Booker. By an unknown New Zealander, published by a tiny feministcollective publisher, with a complex structure and style including considerable use of Maori words, it was an esoteric selection. The "selection of Keri Hulme's 'The Bone People' was so eccentric, it sparked a grass-roots revolt," according to David Lehman. One positive review nevertheless stipulated its difference from the standard Booker winner: "Under the eccentricities of layout and fused words there's a melodrama, 
a soap opera, that exerts a strong hold" (Simpson). In other words, almost the opposite of Hotel du Lac.

In the following year, another well-established middle-aged English author, published by a mainline press located in England (and previously shortlisted), Kingsley Amis, won the prize with The Old Devils. Again, the choice seemed the "safe," mainstream novel, which is not to say that it was undeserving. The pendulum swung back, at least part of the way, in 1988 with the award for Peter Carey's Oscar and Lucinda, an unusual and ambitious novel by a younger Australian author, though the judges stopped short of naming Salman Rushdie's The Satanic Verses, a postmodern, post-colonialist narrative that attracted death threats for Rushdie.

These fluctuations brought the publicity that has always differentiated the Booker from other prizes, even, in some cases, brought "scandal." For many commentators, Hulme's victory, due to the obscurity of its author and the eccentricities of its text, constituted a scandal; in 1988 the accusation that the judges' chair, Labour politician Michael Foot, maneuvered to assure a victory for Rushdie because he was also a member of the Labour Party, whether true or not, struck the traditional scandalous note. They demonstrate the flexibility that is one of the Booker's strengths and the unpredictability and diversity of results that arise from the newevery-year panel of miscellaneous judges. By veering but remaining between the opposite embankments of popular accessibility or genre fiction and difficult complexity or aggressive post-modernism, they embody the genius of the Booker's product placement. And those features, rather than anything about the prize money, the sponsorship, or the rules, explain how the Booker Prize has become, in fifty years of existence, the most important literary prize in the English-speaking world.

\section{Notes:}

${ }^{1}$ One sign of the Booker's success in generating renown is its having inspired multiple novels. The list includes at least Simon Brett's The Booker Book: A Novel (1986); Carmen St. Keeldare's The Booker Prize Fix (1996); Edward St. Aubyn's Lost for Words (2015); and Paul Ewen's Francis Plug: How to Be a Public Author (2015). St. Aubyn's satire is about the lightly-disguised "Elysian Prize"; Ewen's a series of imaginary meetings with Booker-Prize-winning 
novelists. Brett has an aspiring writer who tries to win the Booker because it confers "a kind of seal of approval on the English novel" (7).

${ }^{2}$ One should not overlook the happy chance that named the prize the Booker, a catchy and misleadingly book-related title that comes from the original sponsors, Booker-McConnell plc, a wholesale food company. When it was renamed the Man Booker Prize in 2002, even that retained some publicity value as it quite accidentally tied into widespread criticism of the award for undervaluing women authors. The Man Group is a hedge fund founded by James Man.

3 Another "scandal," as In a Free State consists of three short stories within a narrative frame, which for many commentators did not qualify as a novel.

\section{Works Cited}

Anderson, Willie. “A Bookseller's Perspective.” Booker 30: A Celebration of 30 Years of the Booker Prize for Fiction, 1969-1998. London: Booker, 1998: 26-27.

Bennett, Catherine. "The Man Booker Judges Seem to Find Reading a Bit Hard." The Guardian 10 Sept. 2011. Web. 12 July 2019.

Booker 30: A Celebration of 30 Years of the Booker Prize for Fiction, 1969-1998. London: Booker, 1998.

Brett, Simon. The Booker Book: A Novel. London: Sidgwick, 1989.

Brockes, Emma. "14 $4^{\text {th }}$ Time Lucky." The Guardian 12 Oct. 2005). Web. 12 July 2019.

Brown, Luke. "Contrasting Priorities." The Times Literary Supplement 7 Sept. 2018): 15.

Brown, Mark. "Man Booker Prize Shortlist Includes First Western and Novel by Care Worker." The Guardian 6 Sept. 2011). Web. 12 June 2019.

Cain, Sian. "Publishers Call on Man Booker Prize to Drop American Authors." The Guardian 2 Feb. 2018). Web. 21 July 2019.

Caine, Michael H. “The Booker Story.” Booker 30: 6-12.

Clark, Alex. "Man Booker Prize: This Year's Judges Are Betraying Authors and Their Readers." The Guardian 15 Oct. 2011). Web. 20 Feb. 2019.

Cowley, Jason. "And the Winner Is?" The Guardian Oct. 22, 2006. Web. 14 June 2019.

English, James F. "Winning the Culture Game: Prizes, Awards, and the Rules of Art. New Literary History 33 (Winter 2002): 109-36.

The Goldsmiths Prize website. Web. 14 June 2019.

Hornby, Nick. Housekeeping vs. The Dirt. San Francisco: Believer, 2006.

Lee, Hermione. "From the Archive, 21 October 1984: Why Should the Booker Play Safe?" The Guardian 23 Oct. 2011. Web. 4 July 2019.

Lehman, David. "May the Best Author Win - Fat Chance." Newsweek 21 Apr. 1986: 80. Web. 11 June 2019.

The Man Booker Prize: 35 Years of the Best in Contemporary Fiction, 19692003. London: The Booker Prize Foundation, 2003. 
Maschler, Tom. "How It All Began.” Booker 30: 15-16.

Miller, Laura. "Why the Booker is the Best Literary Award." Salon 13 Oct. 2010. Web. 4 June 2019.

"Never Mind the Quality, Can You Feel the Words?" The Herald (Glasgow) 19 Oct. 2011: 15. Web. 18 July 2019.

Strongman, Luke. The Booker Prize and the Legacy of Empire. Amsterdam: Rodopi, 2002.

Thwaite, Anthony. "Booker 1986.” Encounter Feb. 1987: 32.

Todd, Richard. Consuming Fictions: The Booker Prize and Fiction in Britain Today. London: Bloomsbury, 1996.

Trewin, Ion. "Behind the Scenes: Ion Trewin Interviews Martyn Goff." Booker 30: 19-22.

Wheen, Francis, ed. Lord Gnome's Literary Companion. London: Verso, 1994.

Simpson, Leo. "Eccentricity and Soap Opera: THE BONE PEOPLE." The Globe and Mail (Canada). 4 Jan. 1986: D14. Web. 1 June 2019.

Yeginsu, Ceylan. "Bar Americans From Man Booker Prize, Fed-Up British Authors Urge.” New York Times 30 Mar. 2018). Web. 21 July 2019. 